\title{
Is livestock grazing a key factor for changing vegetation patterns in lime rich coastal dunes in the Netherlands?
}

\author{
Harrie G. J. M. van der Hagen ${ }^{1}$ - Dan Assendorp ${ }^{2} \cdot$ Wim Calame $^{3} \cdot$ Frank van der Meulen $^{4} \cdot$ Karlè V. Sýkora ${ }^{5}$. \\ Joop H. J. Schaminée $e^{5,6}$
}

Received: 26 February 2018 / Revised: 27 January 2020 / Accepted: 4 February 2020 / Published online: 19 February 2020

(C) The Author(s) 2020

\begin{abstract}
In 1990, livestock grazing was introduced in Meijendel, a 1800 ha lime-rich coastal dune area, at a density of $0.06-0.07$ LLU ha $^{-1}$ year $^{-1}$ (1:12-18 ha) to counteract encroachment of tall grasses and shrubland on dune grassland and increase the bare sand area. Monitoring was based on four digital orthophotos (1975-1990-2001-2009) with a high spatial resolution (pixel size $25 \times$ $25 \mathrm{~cm}$ ). The changes were tested using Generalized Estimating Equations. Habitat changes occurred, but contradicting our hypothesis, there was no significant impact from the grazing on bare sand, grassland or shrubland within 11 and 19 years post livestock introduction. (1) After several decennia of decreasing bare sand, there was a significant increase between 2001 and 2009, irrespective of livestock presence. (2) The changes in grasslands and shrublands are independent of the livestock, but dependent on distance to the coast. (3) Bare sand and shrub cover determine the space left for the dune grasslands. It appears other factors than livestock grazing must have induced the changes. Changes in climate conditions and nitrogen load might have stimulated bare sand. An interaction with the end of Marram planting in 1990 cannot be concluded from available data. The disease-led reduction of rabbit grazing from the mid-1950s led to an expansion of the dominant shrub Hippophae rhamnoides. However, Hippophae shrubland typically regresses to grasslands on its collapse after 25-40 years. Tree species like Crataegus, Betula and Quercus will gradually dominate the landscape for far longer. Active removal of these indigenous species is necessary to prevent future loss of dune grasslands.
\end{abstract}

Keywords Coastal dunes $\cdot$ Blowout $\cdot$ Aerial photographs $\cdot$ Livestock grazing $\cdot$ Oryctolagus cuniculus $\cdot$ Hippophae rhamnoides

Electronic supplementary material The online version of this article (https://doi.org/10.1007/s11852-020-00733-z) contains supplementary material, which is available to authorized users.

Harrie G. J. M. van der Hagen

h.hagen@dunea.nl

1 Dunea duin \& water, P.O. Box 756, NL-2700, AT

Zoetermeer, The Netherlands

2 Land and Water Management, Van Hall Larenstein, P.O. Box 9001, NL-6880 GB Velp, The Netherlands

3 StatistiCal BV, Galileiweg 8, NL-2333 BD Leiden, The Netherlands

4 Frank van der Meulen Consultancy, Admiraal de Ruytersingel 56, NL-2253 TX Voorschoten, The Netherlands

5 Plant Ecology and Nature Conservation, Wageningen University, P.O. Box 47, NL-6700 AA Wageningen, The Netherlands

6 Institute for Water and Wetland Research, Radboud University, P.O. Box 9010, NL-6500 GL Nijmegen, The Netherlands

\section{Introduction}

Lime-rich coastal sand dunes in The Netherlands are species rich and harbour 66\% of the Dutch flora (De Vries et al. 1994). Under the Natura 2000 legislation (Council of the European Communities 1992) almost all habitats of the coastal sand dunes are protected. These habitats are a mosaic of bare sand, dune grasslands, shrubland and forests. 'Grey dunes', i.e. fixed coastal dunes with herbaceous vegetation, are designated as a priority habitat type (H2130) by Natura 2000. Grey dunes not only contain a great number of vascular plants, but they are also rich in bryophytes, mosses and lichens (Schaminée et al. 1995, 1996, 1998; Stortelder et al. 1999).

During the last five decades, the vegetation in Dutch coastal dunes has changed considerably. Patches with bare sand and open grasslands have changed into areas mainly dominated by tall grasses and sedges, shrubs and forest that has gradually led to a rather monotonous vegetation and a considerable loss of local biodiversity (Ketner-Oostra and Sýkora 2004; Kooijman et al. 1998; Veer and Kooijman 1997). These processes have been associated with several phenomena: (1) the outbreak of 
Myxomatosis and Viral Haemorrhagic Disease (RVHD) in populations of rabbits (Oryctolagus cuniculus), (2) routine planting of Marram grass (Ammophila arenaria) and shrubs and trees to stabilize dunes, (3) planting of shrub and tree species for mainly aesthetic reasons and wood production, (4) a high input of airborne nitrogen, (5) changes in land use, including abandonment of agricultural practices like livestock grazing and crop cultivation, (6) the impact of changes in climate conditions, (7) an ongoing anthropogenization of the landscape (e.g. recreation), accompanying a rapid spread of introduced non-native species, and (8) autonomous succession (Provoost et al. 2011; Remke et al. 2009; Noordijk 2007; Jones et al. 2004; Eerens and Van Dam 2001; Drees and Olff 2001; Kooijman et al. 1998; Ten Harkel 1998; Ten Harkel and Van der Meulen 1996; Schaminée et al. 1995, 1996, 1998; Stortelder et al. 1999; Bakker et al. 1974; Boerboom and Westhoff 1974; Ranwell 1960). As large herbivores were thought to counteract the process of stabilisation and monotonisation (Van Dijk 1992; Kooijman and De Haan 1995; Provoost et al. 2011) and the fact that large herbivores strongly prefer graminoid species (Lamoot et al. 2005) extensive grazing by domestic livestock has been introduced in many nature reserves in The Netherlands and elsewhere.

In late 1990, year-round grazing by livestock was introduced in the coastal dunes of Meijendel near The Hague, The Netherlands (GPS $52^{\circ} 7{ }^{\circ} \mathrm{N} ; 4^{\circ} 20^{\prime} \mathrm{E}$ ). The livestock density was $0.06-0.07$ LLU ha $^{-1}$ year $^{-1}$ (1:12-18 ha). Generally speaking, Wallis de Vries et al. (1998) consider this to be a relatively low level of impact. However, the level of LLU had been adjusted to the low level of palatable biomass in coastal sand dunes (e.g. Ebrahimi 2007) and expected winter survival of the animals. In some years, some animals of the herds barely survived winter, which meant a relatively high impact on this nutrient-poor environment. By trampling and grazing, the vegetation was expected to be damaged to a large degree, initiating blowouts. Grazing was expected to stop the increase, or even cause a decrease, of shrubs and trees or, at the least, open up the shrubland and forest to the benefit of species rich dune grasslands (see De Bonte et al. 1999).

The hypothesis of this study is that the introduction of livestock will lead to regressive succession, as expressed in an increase of bare sand, a decrease in the area of shrubland, and a subsequent increase of dune grassland. This paper focusses on the changes in area cover of these three classes (bare sand, grassland and shrubland), by comparing three livestock-grazed areas and three ungrazed controls within the coastal dunes of Meijendel in The Netherlands.

\section{Area of investigation}

The dunes of Meijendel are a well-known and highly valued example of the lime-rich dune landscape of the Atlantic coast (Janssen and Schaminée 2003; Van der Meulen and Van der Maarel 1993). Meijendel covers an area of approximately
1800 ha (Van der Meulen et al. 1985). Van der Meulen et al. (1985) distinguished four landscape ecological zones running more or less parallel to the coast with increasing distance from the sea: (i) Fore Dunes; parallel dune ridges mainly with Marram grass, which was extensively planted for stabilisation purposes as a coastal defence measure, (ii) Parabolic Dunes; dunes with a pronounced relief $(2-20 \mathrm{~m})$ and small moist dune valleys in between, whose soils are rich in lime. The drier dunes are mosaics of bare sand, pioneer grasslands (southern exposures), closed grasslands (northern exposures) and shrubs of Sea Buckthorn (Hippophae rhamnoides) and other shrubs; it is the zone for artificial recharge for drinking water production (Fig. 1; open water), (iii) Large Dune valleys; decalcified grasslands and deciduous woodlands where tree species like Betula, Crataegus and Quercus dominate, which in the nineteenth century were partly flattened and used as arable land, and (iv) Inner Dunes; in general higher dunes (5-35 m) with less pronounced parabolic and rolling dunes. The topsoil is partly decalcified and supports dune grasslands with short grasses, mosses and lichens, open Hippophae shrubland and forest patches. Occasional sand blowouts generate a mosaic with grasslands richer in lime.

\section{Material and methods}

\section{Aerial images}

Along the Dutch coast, sequential mapping of aerial photographs have shown drastic changes in vegetation cover (e.g. Van Dorp et al. 1985; Kruijsen et al. 1992; Van Til and Mourik 1999; Janssen 2004), but in complex systems like coastal sand dunes, manual and especially manual sequential mappings have their limitations (Janssen 2004; Assendorp 2010). Drawing lines between vegetation types in discrete landscapes with crisp (sharp) boundaries is relatively easy. But drawing lines in a landscape with fuzzy spatial transitions between vegetation types, such as coastal dunes where every metre can be different to the next, the interpretation of vegetation types is highly dependent on personal interpretation. Therefore, other remote techniques are required and used for vegetation mapping and land surveys (e.g. Campbell 2006; Groom et al. 2006; Potter 2013). Assendorp (2010) demonstrated that geometrically and radiometrically corrected orthophotos with a high spatial resolution largely overcomes the difficulties of manual mapping.

Four sets of high-resolution false colour infrared digital orthophotos of Meijendel were available with clear time intervals: 1975, 1990, 2001 and 2009. All four were taken in the same period of the year (end June/beginning July). The years 1975 and 1990 are \pm 3302 mu scanned analogue images (34 $\times$ $34 \mathrm{~cm}$ ), which have been geo-referenced and radiometrically corrected to one orthophoto. The years 2001 and 2009 were 


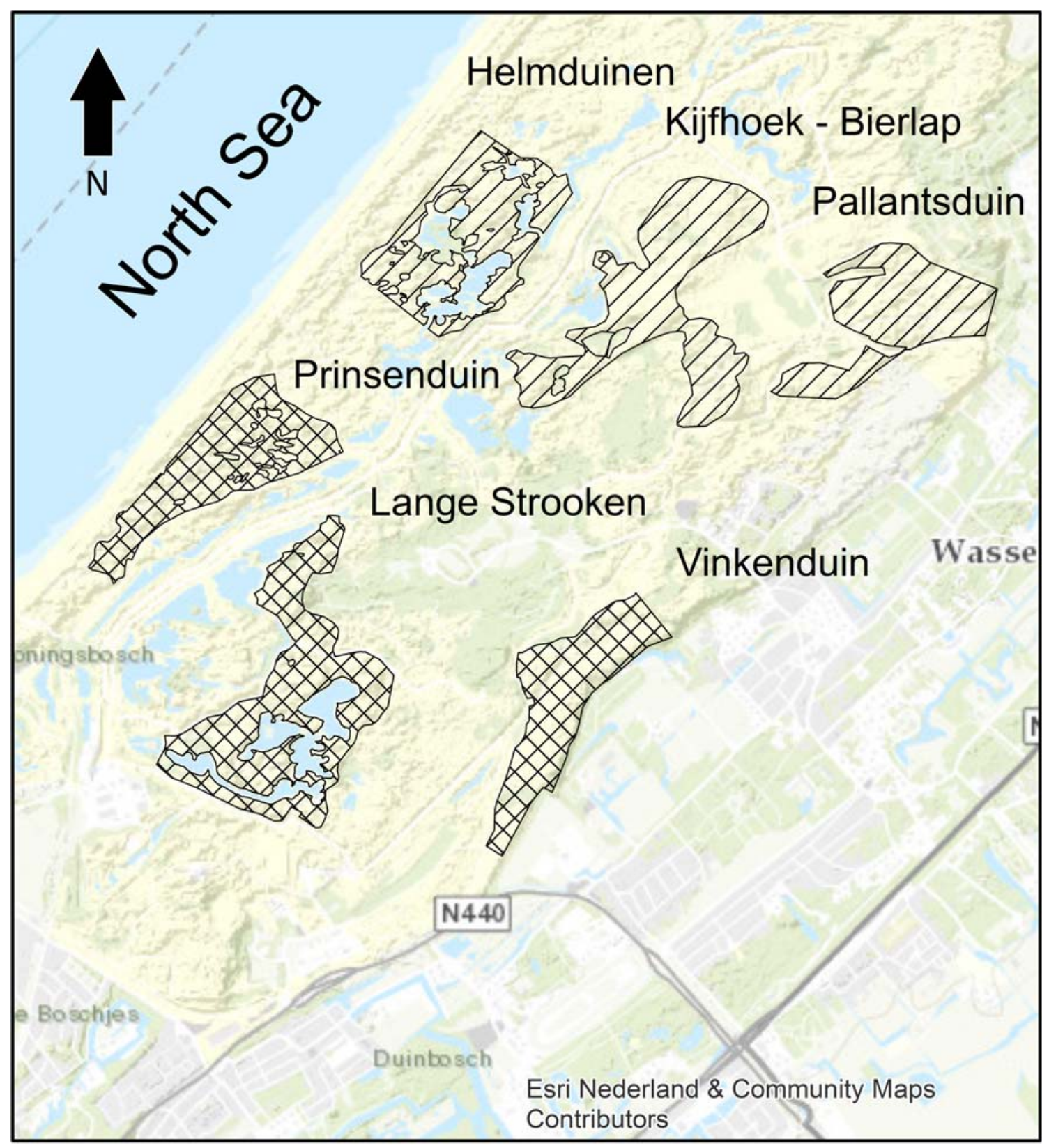

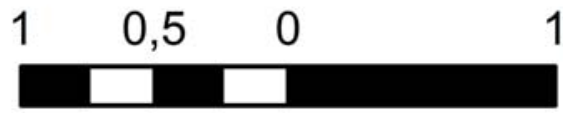

Hillshade with contour line

Open water

Fig. 1 The six study sites in Meijendel, The Netherlands with their area names. The three northern areas are grazed, from West to Central to East: Helmduinen, Kijfhoek/Bierlap, Pallantsduin. The three southern areas are ungrazed - from west to east: Prinsenduin, Lange Strooken, Vinkenduin.

direct digital recordings and also radiometrically corrected. For the technical details of orthophoto production see

\section{Kilometers Legend}

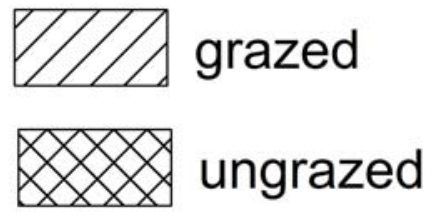

The West and Central areas are in the parabolic landscape zone; the East areas are in the inner dunes. The black outer line separates the sand dunes (with the six study sites) from the urban area with the main road system

Assendorp (2010). The feature space data were processed in ArcGis 10.3. The accuracy of the classification of scanned 
analogue false colour images of 1975 and 1990 and of the digital photos of 2001 and 2009 were $80-95 \%$ as demonstrated by Assendorp (2010). This percentage is generally accepted as appropriate for a vegetation structure map (Foody 2002; Assendorp 2010). All four sets of orthophoto images were resampled to a pixel size of $25 \times 25 \mathrm{~cm}$. At this resolution, bare sand and shrubland/trees are defined (crisp) objects and consist of multiple pixels in the image. Grasslands differ within a $25 \times 25 \mathrm{~cm}$ pixel and have a reflection at the subpixel level (fuzzy). Bare sand has a specific reflection and is easily separated in the feature space (Assendorp 2010) and is defined as $100 \%$ coverage of blond windblown sand without any vegetation cover and no grey humic sand on the surface. Shrubland/trees, defined as $100 \%$ coverage of woody plants, are also easily distinguished from the rest in a traditional supervised image classification (Assendorp 2010). In the six selected areas, the shrubland category consists almost entirely of Hippophae rhamnoides. The grasslands are sharply clustered within one class.

\section{Selection of research areas}

As the focus of this research is on groundwater independent dunes, dune slacks and water bodies were left out and in the case of infiltration ponds given an extra margin of $10 \mathrm{~m}$ around. Similarly, all human-disturbed open areas were left out. These include (i) areas with extraction wells for artificial recharge for drinking water production, (ii) intentionally denuded areas to stimulate blowouts, (iii) the foreshore and Fore Dunes as grazing is prohibited, (iv) parts of the Parabolic dunes which were intentionally planted with shrubs and trees, and (v) the larger dune valleys as these valleys are an unnatural feature, and have no ungrazed counterpart. Up to 1990, all over Meijendel except for the Fore Dunes compulsory plantings of Marram grass was equally applied.

From West to the Central and the East, the test grazing areas are represented by the Helmduinen (43 ha), Kijfhoek/ Bierlap (65 ha) and Pallantsduin (43 ha), whereas Prinsenduin (43 ha), Lange Strooken (65 ha) and Vinkenduin (43 ha) represent the ungrazed control areas (Fig. 1); in total 302 ha. The study areas are positioned within the areas of the (ii) Parabolic Dunes and the (iv) Inner Dunes (Van der Meulen et al. 1985).

In late 1990, year-round grazing with Galloway cattle and Norwegian Fjord horses was started, just after the 1990 orthophotos were taken. It is assumed that the impact of rabbit grazing on the three vegetation classes is equal. The rabbit populations fluctuate over the years because of variations in the impact of epidemic diseases (Myxomatosis from around 1954 and RVHD in 1989, just before the introduction of the livestock). Rabbits are counted, but the transects cross over the areas of this research.

\section{Statistical analysis and confounding factors}

With late 1990 as the starting point of grazing, the changes of the crisp vegetation classes in hectares between 1975 and 1990 as well as between the test starting date of 1990 and 2001 and equally between the test starting date of 1990 and 2009 have each been calculated per research area in order to view time-dependent impact of grazing on the outcome, while acknowledging the changes in impact by starting levels. The interval between 1975 and 1990 is considered as a period without large herbivore grazing. By subtracting the outcome per plot at the various times from status at the start, data are transferred into change values: the change in amount of hectares covered by the various vegetation types per time interval (before and after start of grazing) per period. Two main sets of data were obtained: one with grazing and the other without (control). Subsequently the values were tested as to what extent grazing affected the relative distribution of the three types of vegetation using Generalized Estimating Equations (GEE) analysis with dummy variables (Kleinbaum et al. 1998). As potentially confounding factors, the starting values (at $t=0$ ) and the relative locations in the dune area $(1=$ West; $2=$ Central; 3 = East; Fig. 1) were taken into account as variables. The regression equation (eq. 1) used was:

$y=\left(a_{1} x_{1}\right)+\left(a_{2} x_{2}\right)+\left(a_{3} x_{3}\right)+a_{4}$

in which:

$\boldsymbol{y} \quad$ change in hectares per time interval

$x_{1}$ dummy variable, taking the values 0 for not grazed control area and 1 for grazed area

$x_{2}$ time interval

$\begin{array}{ll}x_{3} & \left(x_{1}\right) \times\left(x_{22}\right)\end{array}$

$a_{1-4}$ coefficients

In a second stepwise regression analysis confusing was checked by the introduction of location: West, East and Central, all coded by a discrete character, and starting value at 1975 to detect potential impact by this factor on the outcome. In the latter analysis, variation in the change of hectares was associated with variation of the above factors, together with dummy coding (0: ungrazed versus 1 : grazed).

Fitting of the equation model was evaluated by Wald Chisquare test. GEE analyses were done using STATA, version 12 (StataCorp, College Station, Texas, US). Graphic representation was performed via GraphPad Prism, version 6 (LaJolla, CA, USA). Throughout the study, using two-sided testing, $P$ values of 0.05 or lower were considered to be of statistical significance.

Apart from the statistical analysis on the changes, the weighted average of the three crisp classes of the three grazed and three ungrazed controls is calculated and fitted to figures in MS Office Excel 2010. 


\section{Results}

\section{Impact by livestock}

For the period of fifteen years before (1975-1990), and respectively eleven (1990-2001) and nineteen (1990-2009) years after the start of livestock grazing, the changes in relation to the start of livestock grazing (1990) are presented (Fig. 2a-c) as well as the weighted average of the three areas of grazed versus ungrazed (Fig. 3a, b). The changes in hectares of bare sand, grassland and shrubland between grazed and ungrazed areas are - in contrast with the hypothesis - not different (Fig. 2a-c; Table 1). A similar conclusion was reached for the mean proportion of the three structural types (bare sand, grassland and shrub; Fig. 3a, b). A decline of bare sand up to 2001 and an increase of shrubland up to 1990, as direct outcomes of progressive succession, is clearly visible in both the grazed and ungrazed control areas.

The results for each crisp class is described in different sections. The classes of bare sand and shrubland are described first, because bare sand and shrub development seem to determine the space left for the dune grasslands.
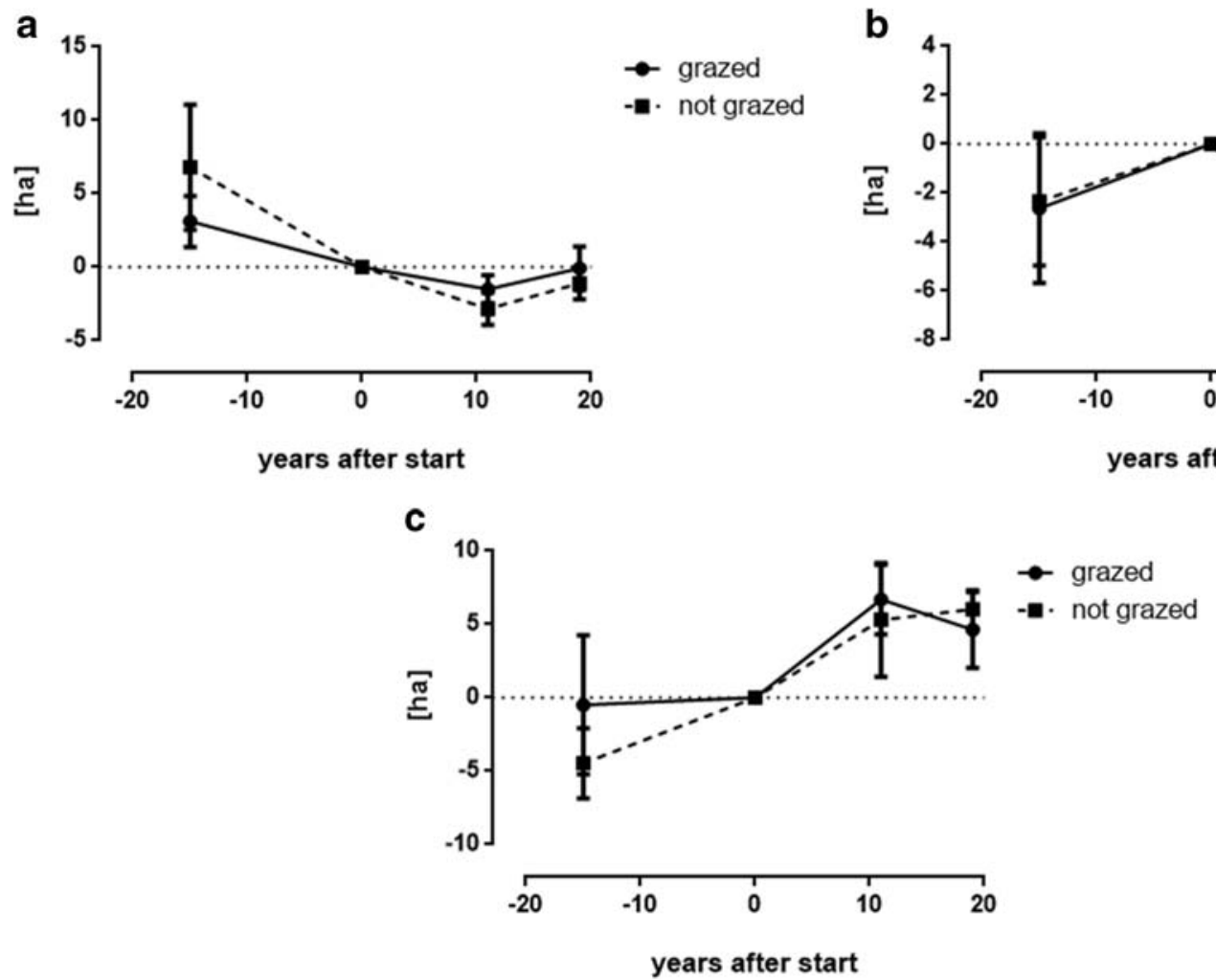

Fig. 2 Changes in relation to the year 1990 of the three classes (bare sand, shrubland, grassland) area cover in hectares; mean $\pm 1 \mathrm{x}$ standard deviation of three grazed and three not grazed areas. (a) Changes in relation to the year 1990 in bare sand area cover in hectares. (b)

\section{Changes in bare sand}

Between 1975 and 1990 and 1990-2001, there is a steady decrease in the area of bare sand. In the period 20012009, an increase in bare sand is visible, though not significant (Fig. 2a; Table 1). Before the introduction of livestock, between 1975 and 1990 aerial photographs show that bare sand mainly evolves into grasslands, but no significant differences could be observed between the grazed and ungrazed areas because in the pre-1990 time frame they were both ungrazed. From 1990 onwards, we expected clear differences due to grazing. Surprisingly, there is no difference between the grazed and the ungrazed areas, and -surprisingly- the change in the ungrazed areas is more pronounced, but statistically not different.

Between 2001 and 2009, there is a clear increase of bare sand both in the grazed and ungrazed sites with no significant difference $(p>0.05$; Table 1$)$. Time $(p<0.04)$ and location $(p<0.01)$ explains the differences in the changes in area of bare sand, irrespective of grazing. There is an overall reduction in the bare sand areas between 1975 and 2009, while the reduction in the central dune area is more pronounced than in the west and the east dune areas. Again, there is no significant effect because of livestock grazing.

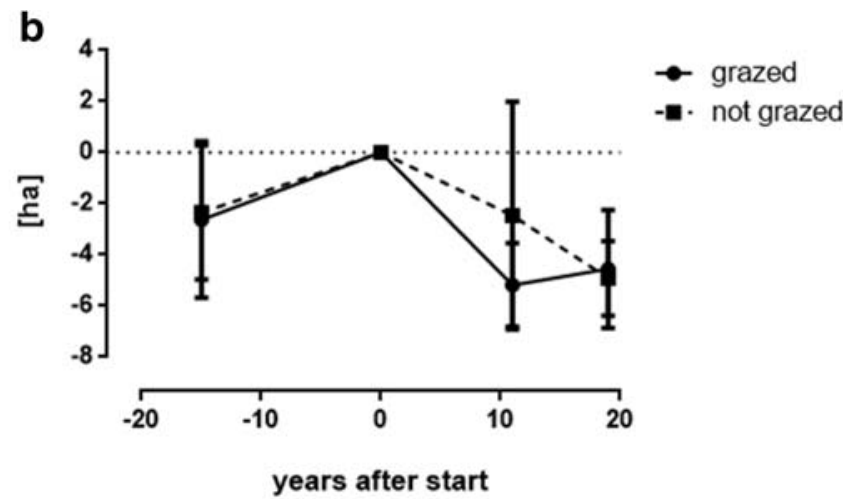

Changes in relation to the year 1990 in shrubland area cover in hectares. (c) Changes in relation to the year 1990 in grassland area cover in hectares 


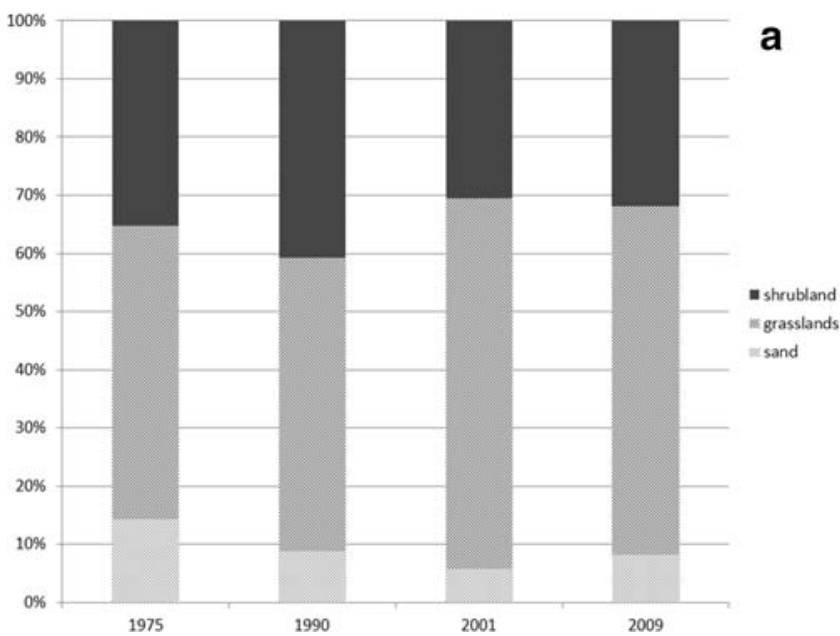

Fig. 3 Weighted average of pixel number of the three crisp classes in the four years; 1990 is the year of introduction of livestock just after the orthophoto flight. The percentages are given in an online appendix

Within the studied time interval of 34 years, the coverage of bare sand varied between $2.7 \%$ and $21.5 \%$ (Fig. 3a, b; online appendix Table 1a, b). The grazed and ungrazed areas show similar trends in bare sand cover. In 1975, the weighted average proportion of bare sand was $14.5 \%$ in the pre-1990 grazed area and $21.5 \%$ in the control. In 1990, it had decreased to $8.9 \%$ and $8.4 \%$ in the post 1990 grazed versus the control area. The lowest percentage was reached in 2001 with $5.8 \%$ and $2.7 \%$ after which it increased to $8.3 \%$ and $6.2 \%$, respectively.

\section{Changes in shrubland}

Between 1975 and 1990 prior to the start of the grazing, shrubland increased by an average of three hectares in both grazed and ungrazed sites (Fig. 2b; Table 1). This is according to the expectations, because all sites were ungrazed before 1990 . Between 1990 and 2001, the average change was a decrease

Table 1 Statistical matrices of the Generalized Estimating Equations analysis and the following stepwise regression analysis checking confounding factors. The number of observations is 12

\begin{tabular}{llllll}
\hline Bare sand & F-value & $\mathrm{R}^{2}$ & t-value & $\mathrm{P}$ value & Significance \\
\hline & $\mathrm{F}_{(2,9)}=4.73$ & 0.51 & & & \\
Grazing & & & 1.84 & 0.099 & $\mathrm{n} . \mathrm{s}$. \\
Time & & & 2.47 & 0.036 & $*$ \\
Shrubland & & & & & \\
& $\mathrm{F}_{(1,10)}=10.46$ & 0.51 & & & \\
Location & & & 3.23 & 0.009 & $* *$ \\
Grassland & & & & & \\
& $\mathrm{F}_{(2,10)}=6.29$ & 0.39 & & & \\
Location & & & -2.51 & 0.031 & $*$ \\
\hline
\end{tabular}

$*=$ significance $<0.05 ; * *=$ significance $<0.01 ;$ n.s. $=$ not significant

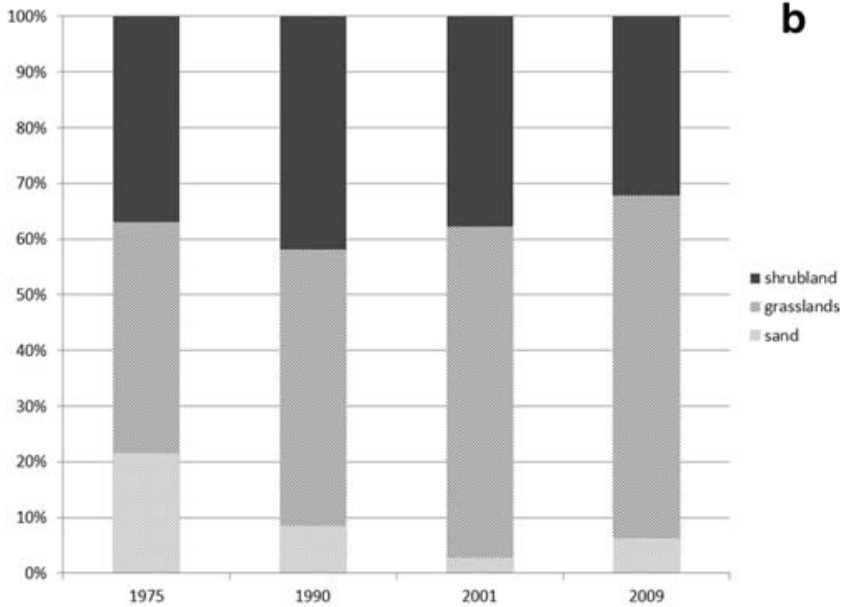

Table 1. (a) Weighted average of the three grazed areas. (b) Weighted average of the three ungrazed areas

of about 4 ha, again in both grazed and ungrazed areas. In between 2001 and 2009 however, there is almost no change in the extent of shrubland. Again, location $(p<0.01)$ is the parameter explaining the changes in shrubland between the grazed and the ungrazed areas. In the west part of the dunes, the decrease in shrub area is significantly $(\mathrm{p}<0.01)$ higher than in the central area with the central being significantly $(\mathrm{p}<0.01$; Table 1$)$ higher than in the east. A clear west to east effect in the reduction in shrubs is demonstrated. In the ungrazed situation of Lange Strooken and Vinkenduin the decline starts in 2001; in the other four areas the decrease started already in 1990. Aerial photographs show an overall regressive succession as when Hippophae shrubs start to die, the shrubs open up and gradually shift to grassland.

In all years and areas, the proportion of shrub varied between 30 to $42 \%$ of the area (Fig. 3a, b; online appendix Table $1 \mathrm{a}, \mathrm{b})$. In all six areas, the dominant shrub is Hippophae rhamnoides. The main changes in coverage are mainly caused by the growth and decline of this species. Between 1975 and 1990, the proportions of shrub increased from 35.2 to $40.7 \%$ (grazed) and from 37 to $41.9 \%$ (ungrazed). Aerial photographs show an expansion of closed thickets of Hippophae shrubs. From 1990 to 2001, this tendency is followed by a decline from 40.7 to $30.5 \%$ (grazed) and from 41.9 to $37.8 \%$ (ungrazed). From 2001 to 2009 , in the grazed area, shrubland increases slightly from 30.5 to $32.0 \%$, whereas in the ungrazed areas the shrubland further decreases from 37.8 to $32.2 \%$ ).

\section{Changes in grasslands}

In the ungrazed areas, the average change between 1975 and 1990 amounts to 5 ha (bare sand changes mainly into grasslands); in the grazed area, almost no changes are observed (Fig. 2c; Table 1). From 1990 to 2001, there is an increase 
of about 5 ha in both the grazed and ungrazed areas. Between 2001 and 2009, the extent of grasslands stabilize but there is a difference by location. The further east, there is a reduced change $(p<0.04)$ to grassland.

The loss of grasslands by the increasing share of bare sand in the period 2001-2009 is explained by a larger decrease in shrubland. Grazing pressure and time variables do not explain the model variables.

In the mosaics of bare sand and shrubland, the dune grassland in all the years of observation and in all areas forms the largest portion of the three crisp classes, illustrating the relative openness of the coastal dune landscape. The dune grassland varies between 41 and $64 \%$ of the area (Fig. 3a, b; online appendix Table 1a, b). Between 1975 and 1990, the extent of grassland in the grazed area remains the same, while in the ungrazed areas the grassland proportion increased from 41.5 to $49.7 \%$, but the changes are different. Between 1990 and 2001, both grazed and ungrazed areas of grassland show an increase of 13.3 and $9.8 \%$, respectively. In the 2001-2009 period, the grassland slightly decreased with $4 \%$ in the grazed area. In the ungrazed situation, the grassland increased slightly by $2.1 \%$.

In overall conclusion, the extent of grasslands is determined by the space left over from the changes in the development of both bare sand and shrubland.

\section{Discussion}

We analysed the effect of the introduction of livestock grazing on changes in the presence and changes in cover extent of the crisp classes of bare sand, grassland and shrubland in the coastal dunes of Meijendel. We hypothesized that due to grazing and trampling caused by the livestock, and the rejuvenating effects of blowouts, the areas of bare sand, and grassland would increase, while simultaneously shrub encroachment at least would be stopped, and even reduced.

Regressive succession occurred, but contrary to our hypotheses, no significant impact of the introduced livestock could be demonstrated in the observed changes of the extent of bare sand, grassland and shrubland with the grazing intensity applied. In the ungrazed areas, similar changes occurred as in the grazed. The question arises which factors could explain this unexpected outcome.

\section{Bare sand}

Which factors can explain the decrease in bare sand up to 2001 and its subsequent increase in all six areas irrespective of livestock grazing?

Bare sand in coastal dunes is normally present as blowouts and in paths. The decrease of bare sand from 1975 until 1990 can be linked to the compulsory planting of Marram grass all over Meijendel as in other dune areas (e.g. Van Dorp et al. 1985;
Van Til 1999). Annually, in Meijendel up to 1.2 million Marram tufts were planted and in many places this was repeated, stimulating a shift towards stabilisation (Van der Meulen and Jungerius 1989; Mensing 2002). In 2001, bare sand mainly consisted of small spots and long paths, as well in the grazed Helmduinen (Fig. 4a) as in the ungrazed Prinsenduin (Fig. 5a). The paths originate from monitoring volunteers, rangers and (illegal) visitors, all taking the same routes over and over again. Though expected, introducing livestock in 1990 did not result in an extra increase of bare sand in the grazed areas. Grazed and ungrazed areas have a similar decrease (Fig. 2a) and shift (Fig. 4a, 5a). Between 2001 and 2009, there is a substantial and comparable increase of bare sand in the grazed Helmduinen (Fig. 4b) as well as in the ungrazed Prinsenduin (Fig. 5b). In 2009 , the paths are still there, but the larger part of the new bare sand is formed by blowouts with areas much broader than paths. These new blowouts are mainly found on slopes with a southwest orientation with climate extremes in spring and summer. Former Marram grass planters confirm that the areas, which were regularly involved in Marram planting, opened up again as part of a natural process irrespective of livestock grazing. Whether the Marram planting hampered the 1990-2001 development of blowouts is impossible to conclude from our data.

Since 1990, the airborne nitrogen load in the dunes has almost halved (Noordijk 2007) and this is likely to have consequences on the increase of bare sand. Primary succession on bare sand starts with algal crusts (Van den Ancker et al. 1985; Pluis and De Winder 1989). Cyanobacteria are the initial colonizers mostly members of the genera Microcoleus, Oscillatoria and Tychonema, in more stable conditions, to be followed by the dominating green algae Klebsormidium flaccidum. These organisms all depend on airborne nitrogen (Pluis and De Winder 1989) and a substantial reduction must have had its implications on the colonization, growth and cohesion of these algal crusts.

A temperature jump in the average mean from $9.2{ }^{\circ} \mathrm{C}$ to $10.5^{\circ} \mathrm{C}$, starting in 1988 (KNMI 2013), and just before the introduction of livestock, is likely to have caused more droughts in the coastal sand dunes stimulating blowouts, irrespective of livestock grazing. Several spring droughts and dry winter winds from the East in the period 2001-2009 are also likely to have stimulated sand blowouts (Aggenbach et al. 2018). Model calculations based on changing climate conditions confirm this theory (Witte et al. 2008, 2012).

On the other hand, changes in climate conditions also led to more intense summer rains and a longer growth period that stimulates an increased and more palatable biomass production over a longer period during a year. Civerolo et al. (2008) found an interaction between a higher nitrogen input and climate change because of higher summer rainfall, making it difficult to pinpoint the changes in our data to any one factor.

This research shows that the location (west, central, east) does not explain the shifts in area of bare sand over time, 
a

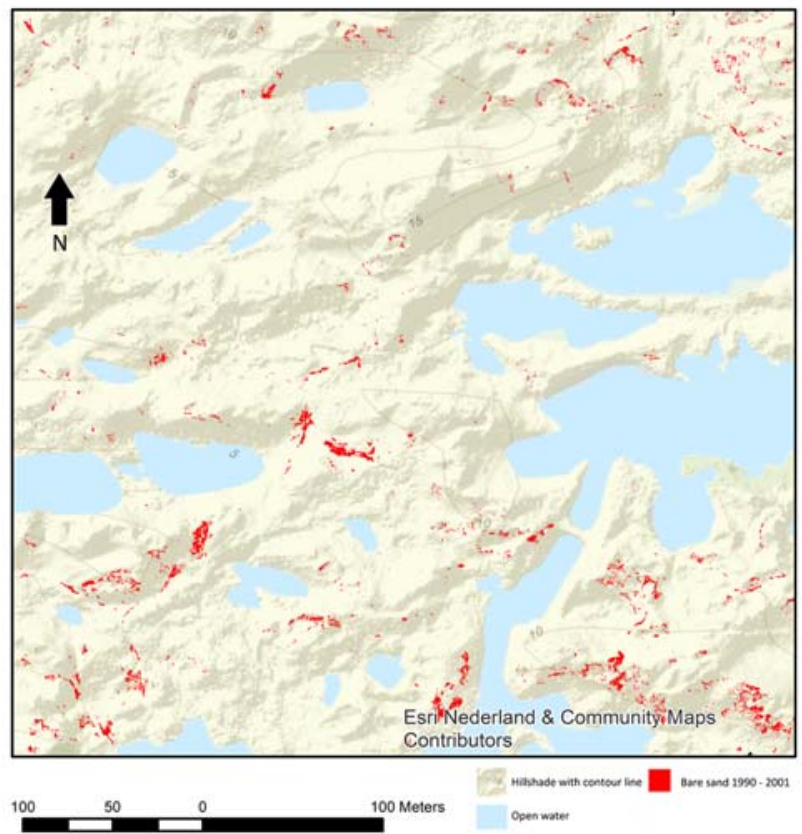

Fig. 4 Major part of the grazed Helmduinen area showing the $25 \times 25 \mathrm{~cm}$ pixels where the land cover changed into bare sand. (a) The changes into bare sand from 1990 to 2001 (red). They are predominantly linear structures in reality observed as paths. (b) The changes from 1990 to

though the wind intensity is presumed to have a greater effect in the western part of the dunes (Arens et al. 2013). Depending on the presence of organic matter, dune sand is more sensitive

a
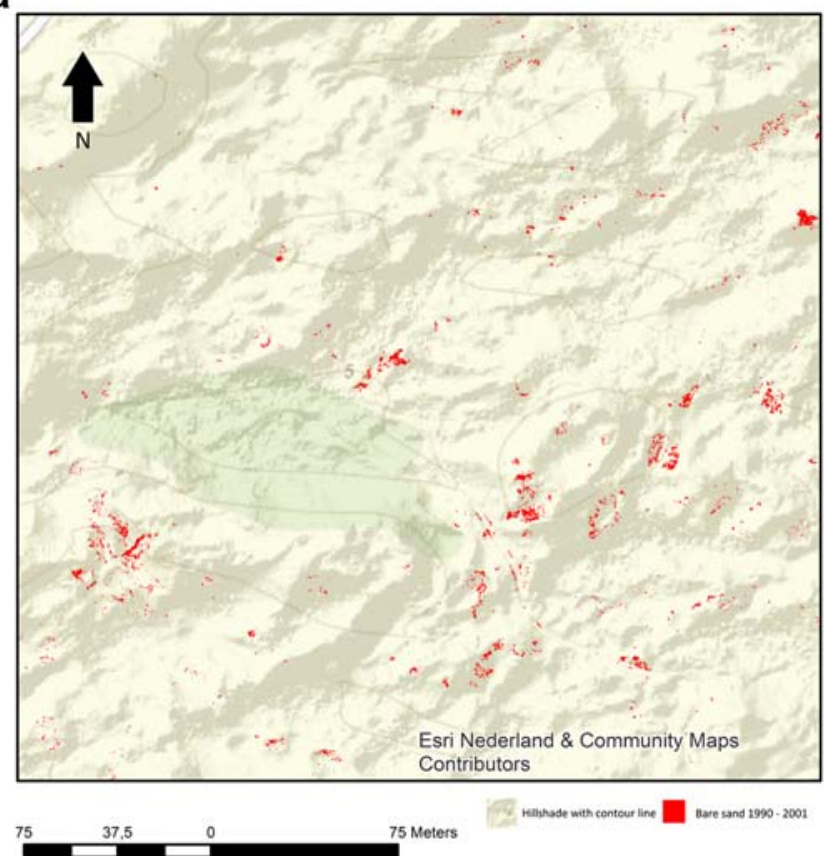

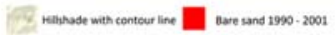

Fig. 5 Major part of the ungrazed Prinsenduin area showing the $25 \times$ $25 \mathrm{~cm}$ pixels where the land cover changed into bare sand. (a) The changes into bare sand from 1990 to 2001 (red). They are predominantly linear structures in reality observed as paths. (b) The b

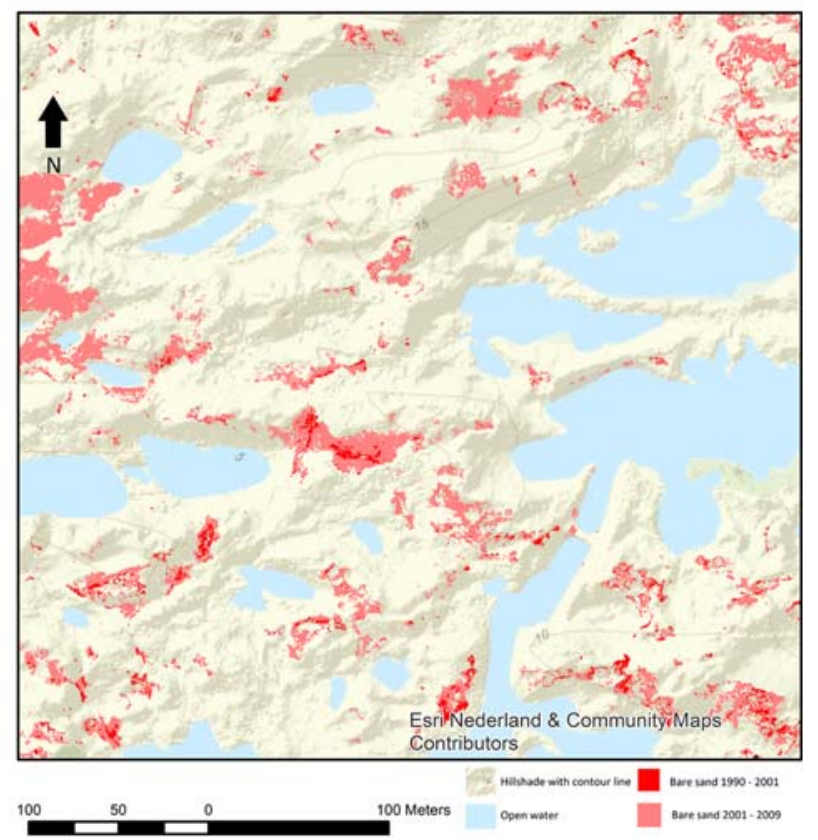

2001 (red) combined with the changes from 2001 to 2009 (pink). The substantial increase in the 2001-2009 period is clearly visible, predominantly surface structures in the field observed as blowouts

to erosion by wind or by water. Yellow lime-rich sand, mainly in the western part of the dune, is without cohesion and is more easily transported away by wind. Further east, grey

b

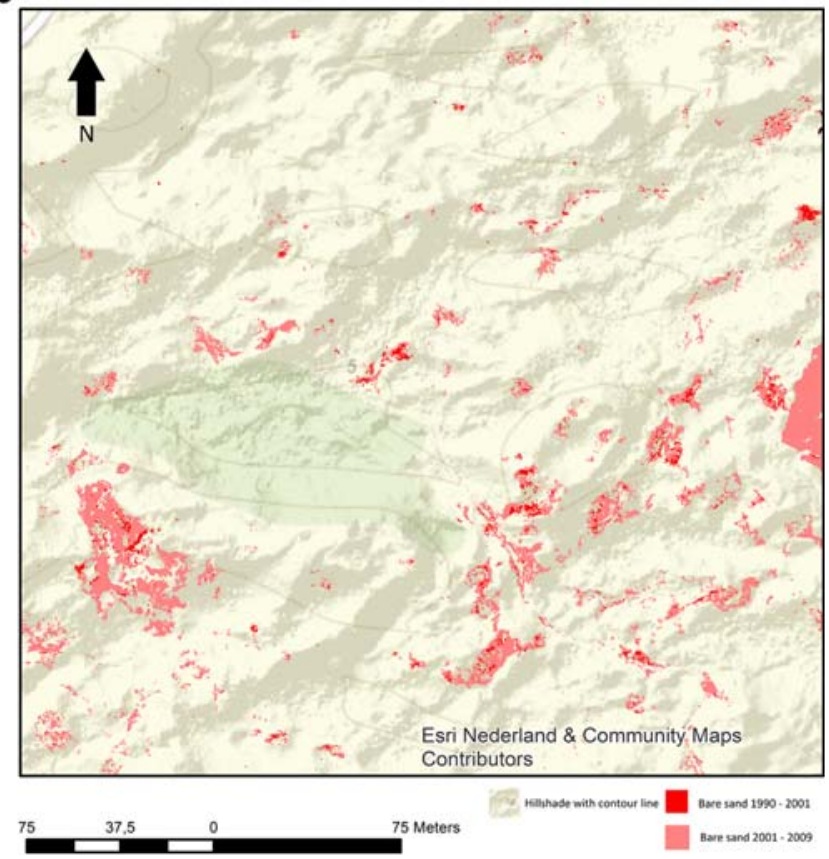

changes from 1990 to 2001 (red) combined with the changes from 2001 to 2009 (pink). The substantial increase in the 2001-2009 period is clearly visible, predominantly surface structures in the field observed as blowouts 
lime-poor top soils contains more organic matter. This sand resists wind erosion, but because of its water repellency, the top layer can be easily washed downslope and this happens especially with heavy rainfall after a period of dry weather. Once the top layer is eroded, wind erosion picks up the underlying yellow sand leading to blowouts (Jungerius and Van der Meulen 1988). Between 2001 and 2009, it is believed that both processes lead to a substantial and comparable increase of bare sand.

Apart from changing nitrogen loads and changing climate factors, very slow increasing numbers of rabbits since the outbreak of RVHD in 1989 might lead to more collapsing warrens in all areas resulting in more points where wind erosion processes could take hold.

\section{Shrubland}

Rabbit grazing is likely to have an great impact on the shifts in shrubland. Rabbits not only graze the grasslands, have warrens, which can collapse that opens up the land to wind erosion, but especially favour nutrient rich seedlings of shrub and tree species (Jungerius and Van der Meulen 1988; Drees and Olff 2001; Van Tongeren 2006). The increase of shrubland can be explained by sudden and steep decreases in rabbit densities due to two rabbit diseases, which became epidemic in Meijendel. These are Myxomatosis from around 1954 and RVHD from around 1989 (Drees and Olff 2001; Scheffer 2012). Myxomatosis is considered by site managers to be responsible for shrubland increase between 1975 and 1990 and for its unexpected decrease between 1990 and 2001 (Fig. 3a, b). Hippophae rhamnoides can grow in nutrient poor and sandy pioneer conditions due to bacterial nodules on its roots (Oremus 1982). In the absence of rabbit grazing in the years directly after 1954, many seedlings or young sprouts of shrub species, including Hippophae, survived. The young plants invaded the surrounding area through clonal spreading, forming male and female monocultures of Hippophae shrubs. The life span of this shrub is about 25-40 years (Zoon 1995). The degeneration process is initiated by nematodes causing malfunctioning of the root nodules (Oremus 1982; Maas et al. 1983; Zoon 1986, 1995), finally resulting in dieback of the plants (Westhoff and Van Oosten 1991). The massive expansion from 1954 would therefore logically lead to a massive decrease starting around 1985 (Fig. 2b; 3a, b). Hippophae shrubs typically return to grasslands (regressive succession: this study; see also Provoost et al. 2011; Cornelissen et al. 2014), but the fine scale analysis of $25 \times 25 \mathrm{~cm}$ field size pixels reveals the degenerating process at an earlier stage and better than manual mapping. On the other hand, new blowouts can generate new opportunities for Hippophae especially in a low density of rabbits due to both diseases being still epidemic. Provoost et al. (2011) report that livestock grazing in Calamagrostis epigejos dominated grasslands also led to a renewal of Hippophae shrubs, but in the Meijendel situation, the decreases outweigh (local) increases. This degenerating process has also been noticed in other dune areas (Aggenbach et al. 2017). The process is the same in all six areas, but the changes in the extent of shrubland are related to the location and the area seems to be smallest in the eastern areas. Hippophae rhamnoides as a pioneer species, has a preference for lime rich sands, which are devoid of nematodes feeding on its root nodules. The chances of finding these favoured conditions diminish from west to east, leading to reduced Hippophae populations.

The shrub Crataegus monogyna and tree species Betula pendula, B. pubescens and Quercus robur also demonstrate similar rabbit-related expansions in Meijendel. In the mid 1970 's, tree ring research in Meijendel was done on Crataegus within a sea-to-inland transect (three kilometres west-east). About $80-85 \%$ of all Crataegus specimens originated from the first few years after the outbreak of myxomatosis in 1954 (Salman and Van der Meijden 1985). Due to the life span of Crataegus (200 years or more), this species might eventually dominate the dunes in future decades before a massive collapse in 150 years time. A relatively sudden decline of Betula pubescens in the dune valley Bierlap (30 ha) in Meijendel was considered to be related to a lowering of the water table due to the extraction of groundwater. This was not the case (Van der Meulen and Wanders 1985). Sequential vegetation mapping showed the real cause of its expansion and decline (Maasdam 1988). Aerial photographs of 1938 showed that Betula invaded most of the valley from west to east after the abandonment by the farmers around 1890. Later years $(1962,1975,1980)$ showed that the degeneration of Betula forest also went from west to east through the valley. Most of the Betula trees had disappeared by 1985 (Maasdam 1988). Based on the nutrient poor soil of the Bierlap valley, these Betula trees had a life span of about 70-90 years (see Fitter and Peat 1994; Beck et al. 2016). Prunus spinosa in the riverine sand dunes of Junner Koeland (The Netherlands) shows the same life span process of increase after myxomatosis and its latter collapse (pers. comm. J. Bokdam; M. Gleichmann).

\section{Dune grasslands}

In traditional progressive succession schemes, grasslands are the outcome of stabilized sand overgrown by vascular plants and mosses after a period of algal crusts. This process takes several decennia (Mensing 2002; Arens et al. 2007, 2009). These grasslands are gradually invaded by shrub species, which expand, and with progressive succession end up as dune forest, reducing the grassland area. In Meijendel, the shrub encroachment is related to the sudden collapse of the rabbit population due to diseases, starting with the 1954 myxomatosis, offering sudden opportunities for seedlings and 
young sprouts of Hippphae rhamnoides and other shrub and tree species. Over a period of 35 years, Hippophae shrub increased at the expense of the grassland area. Due to aging, the shrub collapses and grasslands re-emerge (regressive succession). Because of the now acidified soil, the species composition will differ in the grassland compared to before the Hippophae expansion.

On the other hand, because of the increase of bare sand since 2001, the extent of the grasslands decrease in all research areas irrespective of livestock grazing. This means that it is plausible that -at least in the Meijendel situation- the changes in the extent of space for the grasslands is dictated by the increase and decrease of bare sand and of shrubland; grasslands fill in any left-over space. The regressive succession from Hippophae shrubland into grassland has also been noticed in other areas (Aggenbach et al. 2017) and is likely to be a regular phenomenon along the lime-rich coastal sand dunes. But this also means that apart from bare sand taking a part of the total grassland share, the cutting of indigenous long living shrubs and trees (like Crataegus and Quercus) is unavoidable to maintain a large amount of the EC priority (Council of the European Communities 1992) grasslands habitat.

Acknowledgements First of all we thank Dunea, the dune drinking water company that manages the Meijendel dunes, for giving the opportunity for this study and financing it. The initiative and support of Georgette Leltz, at the start of the research head of the department of Customers \& Nature of Dunea, is gratefully acknowledged. Many thanks to my fellow $\mathrm{PhD}$ Nils van Rooijen discussing the results and helping out on the manuscript. We thank the reviewers for their useful comments on the first draft of the manuscript. Christopher Briggs is gratefully acknowledged for improving the English for the revised manuscript.

Open Access This article is licensed under a Creative Commons Attribution 4.0 International License, which permits use, sharing, adaptation, distribution and reproduction in any medium or format, as long as you give appropriate credit to the original author(s) and the source, provide a link to the Creative Commons licence, and indicate if changes were made. The images or other third party material in this article are included in the article's Creative Commons licence, unless indicated otherwise in a credit line to the material. If material is not included in the article's Creative Commons licence and your intended use is not permitted by statutory regulation or exceeds the permitted use, you will need to obtain permission directly from the copyright holder. To view a copy of this licence, visit http://creativecommons.org/licenses/by/4.0/.

\section{References}

Aggenbach CJS, Arens SM, Kooijman A, Neijmeijer T, Nijssen M, Stuyfzand PJ, Van Til M, Van Boxel J, Commeraat LH (2018) Herstel Grijze duinen door reactivering kleinschalige dynamiek. 2017/OBN 67-DK. Vereniging van Bos- en Natuureigenaren, Driebergen, p 352

Arens SM, Geelen L, Van der Hagen H, Slings QL (2007). Duurzame verstuiving in de Hollandse duinen; kans, droom of nachtmerrie.
Eindrapport fase 1. RAP2007.02 Arens Bureau voor Strand- en Duinonderzoek in opdracht van Waternet, DZH, PWN

Arens SM, Geelen L, Van der Hagen H, Slings QL (2009). Duurzame verstuiving in de Hollandse Duinen; Kans, droom of nachtmerrie. Eindrapport Fase 2. RAP2009.03. Arens Bureau voor Strand- en Duinonderzoek in opdracht van Waternet, PWN, Dunea

Arens SM, Slings QL, Geelen LHWT, Van der Hagen HGJM (2013). Restoration of dune mobility in the Netherlands. In: Luisa Martinez M, Gallego-Fernández JB, Hesp PA (ed) restoration in coastal dunes. Springer series on environmental management, pp 107-124

Assendorp D (2010). Classification of pattern and process in small-scale dynamic ecosystems; with cases in the Dutch coastal dunes. Dissertation, Universiteit van Amsterdam

Bakker K, Bosch H, Van Crevel R, Croin Michielsen N, Drost G, Wanders EAJ, Westhoff V, Van Wijngaarden M (1974). Meijendel, duin-water-leven. Uitgave Duinwaterleiding van 's-Gravenhage

Beck P, Caudullo G, De Rigo D, Tinner W (2016). Betula pendula, Betula pubescens and other birches in Europe: distribution, habitat, usage and threats. In: san-Miguel-Ayanz J, De Rigo D, Caudullo G, Houston Durrant T, Mauri a (Eds) European atlas of Forest tree species. Publ. Off. EU, Luxembourg, pp. e010226+

Boerboom JHA, Westhoff V (1974). Samenlevingen van planten in het duin. In: Bakker K, Bosch H, Van Crevel R, Croin Michielsen N, Drost G, Wanders EAJ, Westhoff V, Van Wijngaarden M (ed) Meijendel, duin-water-leven. Uitgave Duinwaterleiding van 'sGravenhage, pp 70-83

Campbell JB (2006) Introduction to remote sensing. Taylor \& Francis, London

Cornelissen P, Bokdam J, Sýkora KV, Berendse F (2014) Effects of large herbivores on wood pasture dynamics in a European wetland system. Basic and Applied Ecology 15:396-406

Council of the European Communities (1992). Council Directive 92/43/ EEC of 21 May 1992 on the conservation of natural habitats and of wild fauna and flora, 22-7-1992

De Bonte AJ, Boosten A, Van der Hagen HGJM, Sýkora KV (1999) Vegetation development influenced by grazing in the coastal sand dunes near the Hague, the Netherlands. J Coast Conserv 5:59-68

De Vries W, Klijn JA, Kros J (1994) Simulation of long-term impact of atmospheric deposition on dune ecosystems in the Netherlands. J Appl Ecol 31:59-73

Drees JM, Olff H (2001). Rabbit grazing and rabbit counting. In: Houston JA, Edmonson SE, Rooney PJ (ed) Coastal dune management. Shared experiences of European conservation practices. Liverpool University Press, Liverpool, pp 86-95

Ebrahimi A (2007) Towards an integrated framework of determining grazing capacity in low-productive spatially heterogeneous landscapes. Dissertation, Ghent University

Eerens HC, Van Dam JD (2001). Grootschalige luchtverontreiniging en depositie in de Nationale Milieuverkenning 5, rapport 408129016, Rijksinstituut voor Volksgezondheid en Milieu, Bilthoven

Fitter AH, Peat HJ (1994) The ecological Flora database. J Ecol 82:415425

Foody GM (2002) Status of land cover classification accuracy assessment. Remote Sens Environ 80:185-201

Groom G, Mücher CA, Ihse M, Wrbka T (2006) Remote sensing in landscape ecology: experiences and perspectives in European context. Landsc Ecol 21:391-408

Janssen JAM (2004) The use of sequential vegetation maps for monitoring in coastal areas. Community Ecology 5:31-43

Janssen JAM, Schaminée JHJ (2003). Habitattypen; Europese natuur in Nederland. KNNV Publishers Utrecht

Jones MLM, Wallace HL, Norris D, Britain SA, Haria S, Jones RE, Rhind PM, Reynolds BR, Emmett BA (2004) Changes in vegetation and soil characteristics in coastal sand dunes along a gradient of atmospheric nitrogen deposition. Plant Biol 6:598-605 
Jungerius PD, Van der Meulen F (1988) Erosion processes in a dune landscape along the Dutch coast. Catena 15:217-228

Ketner-Oostra R, Sýkora KV (2004) Decline of lichen diversity in calcium-poor coastal dune vegetation since the 1970s related to grass and moss encroachment. Phytocoenologia 34:521-549

Kleinbaum DG, Kupper LL, Muller KE, Nizam A (1998) Applied regression analysis and other multivariable methods, 3rd edn. Duxbury Press, California

KNMI (2013) KNMI DataCentre waarnemingen\&rekenmodellen. KNMI url: https://data/knmi.nl/portal/KNMI-DataCentre.html\#location=nl\&tabdetail=quality

Kooijman AM, De Haan MWA (1995) Grazing as a measure against grass encroachment in Dutch dry dune grasslands: effects on vegetation and soil. J Coast Conserv 1:127-134

Kooijman AM, Dopheide JCR, Sevink J, Takken I, Verstraten JM (1998) Nutrient limitations and their implications on the effects of atmospheric deposition in coastal dunes: lime-poor and lime-rich sites in the Netherlands. J Ecol 86:511-526

Kruijsen BJWM, Slings QL, Snater H (1992). Vegetatiekartering Noordhollands Duinreservaat 1982-1989. NV PWN Waterleidingbedrijf Noord-Holland

Lamoot I, Meert C, Hoffmann M (2005) Habitat use of ponies and cattle foraging together in a coastal dune area. Biol Conserv 122:523-536

Maas PWT, Oremus PAJ, Otten H (1983) Longidorus spec. And Tylenorhynchus microphasmis Loof in growth and nodulation of seabuckthorn (Hippophae rhamnoides). Plant Soil 73:141-147

Maasdam WAC (1988). Een halve eeuw vegetatiesuccessie in de duinvallei Bierlap, Meijendel, 1938-1985. Een sequentieel luchtfoto-onderzoek in combinatie met een geografisch informatie systeem. Universiteit van Amsterdam, Amsterdam; Duinwaterleiding van 's-Gravenhage

Mensing V (2002) Vegetatiesuccessie van stuifkuilen in de Noorderpan (Meijendel) 1978-1997. Een onderzoek naar aanleiding van verstuivingsbeheer 1978-1997 in de Noorderpan. Doctoraal Scriptie IBED / Universiteit van Amsterdam

Noordijk H (2007) Nitrogen in the Netherlands over the past five centuries. In: Monteny G-J, Hartung E (eds) Ammonia emissions in agriculture. Wageningen Academic Publishers, Wageningen

Oremus PAJ (1982) Growth and nodulation of Hippophae rhamnoides L. In the coastal sand dunes of Tthe Netherlands. Dissertation, University of Utrecht

Pluis JLA, De Winder DB (1989) Spatial patterns in algae colonization of dune blowouts. Catena 16:499-506

Potter C (2013) Ten years of land cover change on the California coast detected using landsat satellite image analysis: part 1 - Marin and San Francisco counties. J Coast Conserv 17:697-707

Provoost S, Jones MLM, Edmondson SE (2011) Changes in landscape and vegetation of coastal dunes in Northwest Europe: a review. J Coast Conserv 15:207-226

Ranwell DS (1960) Newborough Warren, Angelsey: III Changes in the vegetation on parts of the dune system after the loss of rabbits by myxomatosis. Journal of Ecology 48:385-395

Remke E, Brouwer E, Kooijman AM, Blindow E, Esselink H, Roelofs H (2009) Even low to medium nitrogen deposition impacts vegetation of dry, coastal dunes around the Baltic Sea. Environ Pollut 157:792800

Salman A, Van der Meijden E (1985) De opmars van de Meidoorn in de Wassenaarse duinen. Duin 1:6-10

Schaminée JHJ, Weeda EJ, Westhoff V (1995) De Vegetatie van Nederland 2. Wateren, moerassen, natte heiden. Opulus Press, Uppsala, Leiden

Schaminée JHJ, Stortelder AHF, Weeda EJ (1996) De Vegetatie van Nederland 3. Graslanden, zomen, droge heiden. Opulus Press, Uppsala ,Leiden
Schaminée JHJ, Weeda EJ, Westhoff V (1998) De Vegetatie van Nederland 4. Kust, binnenlandse pioniermilieus. Opulus Press, Uppsala, Leiden

Stortelder AHF, Schaminée JHJ, Hommel PWFM (1999) De Vegetatie van Nederland 5. Ruigten, struwelen, bossen. Opulus Press, Uppsala, Leiden

Scheffer M (2012) Critical transitions in nature and society recently. Princeton University Press

Ten Harkel MJ (1998). Nutrient pools and fluxes in dry coastal dune grasslands. Dissertation, University of Amsterdam

Ten Harkel MJ, Van der Meulen F (1996) Impact of grazing and atmospheric deposition on the vegetation of dry coastal dune grasslands. J Veg Sci 7:445-452

Van den Ancker JAM, Jungerius PD, Mur R (1985) The role of algae in the stabilization of coastal dune blowouts. Earth Surf Process Landf 10:189-192

Van der Meulen F, Jungerius PD (1989) Landscape development in Dutch coastal dunes: the breakdown and restoration of geomorphological and geohydrological processes. Proceedings of the Royal Society of Edinburgh. Secton B. Biological Sciences 96:219-229

Van der Meulen F, Van der Maarel E (1993) Dry coastal ecosystems of the central and southwestern Netherlands. In: van der Maarel E (ed). Ecosystems of the world 2A, Dry coastal ecosystems. Elsevier, Amsterdam, pp 271-306

der Meulen V, Wanders EAJ (1985) Dynamics and management of some coastal dune woodlands near the Hague. Vegetatio 62:457-465

Van der Meulen F, Wanders EAJ, Van Huis JC (1985) A landscape map for management of coastal dunes of Meijendel, the Netherlands. ICT Journal 2:85-92

Van Dijk HWJ (1992) Grazing domestic livestock in Dutch coastal dunes: experiments, experiences and perspectives. In: Carter RWG, Curtis TG, Sheehy-Skeffington MJ (eds) Coastal dunes: geomorphology, ecology and management for conservation. Balkema, Rotterdam, pp 235-250

Van Dorp D, Boot R, Van der Maarel E (1985) Vegetation succession on the dunes near Oostvoorne, the Netherlands, since 1943, interpreted from air photographs and vegetation maps. Vegetatio 58:123-136

Van Til M, Mourik J (1999) Hiëroglyfen in het zand; vegetatie en landschap van de Amsterdamse Waterleidingduinen. Gemeentewaterleidingen, Amsterdam

Van Tongeren OFR (2006) Overleving van kiemplanten van houtige soorten in relatie tot begrazing. Data-analyse Ecologie, Arnhem

Veer MAC, Kooijman AM (1997) Effects of grass-encroachment on vegetation and soil in Dutch dry dune grasslands. Plant \& Soil 192:119 128

Wallis De Vries MF, Bakker JP, Van Wieren SE (1998) Grazing and conservation management. Kluwer Academic Publishers, Dordrecht

Westhoff V, Van Oosten MF (1991) De plantengroei van de Waddeneilanden. Koninklijke Nederlandse Natuurhistorische Vereniging, Den Haag

Witte JPM, Bartholomeus RP, Cirkel DG, Kamps PWTJ (2008) Ecohydrologische gevolgen van klimaatverandering voor de kustduinen van Nederland. Kiwa Water Research, Nieuwegein

Witte JPM, Bartholomeus RP, Voortman BR, Van der Hagen H, Van der Zee SEATM (2012) Droge duinvegetatie zeer zuinig met water. Landschap 29:109-117 (with English summary)

Zoon FC (1986) On the relative involvement of nematodes and other soil factors in the decline of Hippophae rhamnoides $\mathrm{L}$ in The Netherlands Revue Nematology 9

Zoon FC (1995) Biotic and abiotic soil factors in the succession of sea buckthorn. Dissertation, Landbouwuniversiteit Wageningen, Hippophaë rhamnoides L. in coastal sand dunes

Publisher's note Springer Nature remains neutral with regard to jurisdictional claims in published maps and institutional affiliations. 